\title{
Rækkefølgen af valensændrende affikser i polysyntetiske sprog
}

\author{
Jessie Leigh Nielsen
}

\begin{abstract}
This study examines the ordering of applicative, antipassive, and causative verbal affixes in comparison to the verbal root in polysynthetic languages. Previous studies have found strong crosslinguistic ordering tendencies pertaining to verbal affixes, but so far no large scale studies of the ordering of valency-changing affixes have been conducted. Based on a genetically and geographically stratified sample of 50 polysynthetic languages, this paper presents preliminary results on the ordering of applicatives, antipassives, and causatives. Although the study does not find clear results, it provides a theoretically based hypothesis on the ordering of valency-changing affixes and identifies problems with working with a small sample, suggesting that future studies include more data.
\end{abstract}

Nøgleord: valensændrende afledninger, polysyntetiske sprog, affikser, antipassiv, applikativ, kausativ

\section{Indledning}

Flere studier har fundet tværsproglige tendenser for rækkefølgen af verbalaffikser i forhold til verbalroden som synes at afspejle skopustendenser mellem de pågældende affikser: Affikser med bredt skopus står som regel længere fra verbalroden end affikser med snævert skopus (fx. Bybee 1985, Boye 2012). Tidligere studier har først og fremmest beskæftiget sig med valensbevarende affikser inden for kategorier som tempus, aspekt og evidentialitet hvorimod valensændrende affikser som passiver og applikativer er blevet behandlet som én ensartet kategori der som regel står tættere på verbalroden end de valensbevarende affikser (Bybee 1985: 82).

I denne artikel præsenterer jeg udvalgte resultater fra en tværsproglig 
undersøgelse hvis mål er at finde ud af om der findes tendenser for rækkefølgen af valensændrende affikser og at beskrive eventuelle tendenser. Mere præcist gennemgår jeg i artiklen data for tre typer valensændrende affikser: antipassiver, applikativer og kausativer. Ud fra teorien om at rækkefølgetendenser indirekte afspejler konceptuelle dependenser mellem affikser præsenterer jeg en hypotese baseret på Dansk Funktionel Lingvistiks model for lagdelt indholdsstruktur som bliver testet på data fra et sample på 50 polysyntetiske sprog. Dataene giver ikke et entydigt svar på hypotesen men klarlægger hvordan man sikrer bedre resultater i fremtidige studier.

Artiklen er bygget op på følgende måde: I afsnit 2 og 3 introducerer jeg begrebet 'valensændrende' og gør rede for sammenhængen mellem rækkefølgen af affikser, deres skopusforhold og konceptuel dependens. I afsnit 4 præsenterer jeg undersøgelsens hypotese, og i afsnit 5 beskriver jeg undersøgelsens metode. Afsnit 6 består af en gennemgang af data, og i afsnit 7 diskuterer jeg om dataene stemmer overens med undersøgelsens hypotese, og hvordan man kan opnå klarere resultater i fremtidige studier.

\section{Valensændrende affikser}

Verbalaffikser er traditionelt blevet delt op i to grupper: bøjning og afledning. Disse to grupper er dog defineret ud fra strukturelle kriterier, hvilket gør det svært at gøre brug af distinktionen i tværsproglige undersøgelser ud fra antagelsen om at strukturelle fænomener ikke umiddelbart kan sammenlignes på tværs af sprog (Haspelmath 2010: 665). Derfor er mange typologer begyndt at skelne mellem valensbevarende og valensændrende affikser fremfor bøjning og afledning (fx Kulikov 2011, Kittilä 2011). Valensbevarende verbalaffikser påvirker ikke verbets argumentstruktur men beholder det samme antal og den samme type argumenter verbet kræver. Ofte er affikser som udtrykker fx aspekt eller evidentialitet valensbevarende. Modsat defineres valensændrende affikser som affikser der påvirker et verbums argumentstruktur enten ved at tilføje eller fjerne et direkte argument eller ved at ændre typen af participanter som kan udtrykkes ved et direkte argument (Kulikov 2011). Denne undersøgelse beskæftiger sig med tre frekvente typer valensændrende affikser: antipassiver, applikativer og kausativer. Definitionerne af de tre typer affikser er følgende:

(1a) Antipassiv: Fjerner en ikke-agent fra en position som direkte argument, men tilstedeværelsen af en ikke-agent er stadig impliceret (jf. Foley 2007: 429). 
(1b) Applikativ: Tilføjer en ikke-agent som et direkte argument (jf. Haspelmath 2011: 558).

(1c) Kausativ: Tilføjer en agent (eller 'causer') som et direkte argument der i den afledte konstruktion får agenten i den uafledte konstruktion til at udføre den handling som verbet betegner (jf. Haspelmath 2011: 558).

\section{Rækkefølge og konceptuel dependens}

Tidligere undersøgelser viser at der er tværsproglige tendenser for rækkefølgen af verbalaffikser i forhold til verbalroden, og at rækkefølgetendenser og skopusforhold stemmer overens sådan at affikser med snævert skopus generelt står tættere på verbalroden end affikser med bredt skopus.

For eksempel finder Boye 2012 en tværsproglig rækkefølgetendens for affikser som udtrykker henholdsvis tempus, epistemisk modalitet og illokution. Affikserne står som regel i rækkefølgen beskrevet i (2).

rod - tempus - epistemisk modalitet - illokution (Boye 2012: 244)

Her stemmer rækkefølgen overens med skopustendenser mellem affikserne. Affikser som udtrykker illokutionstype har oftest skopus over epistemisk modale affikser, som oftest har skopus over tempus-affikser (Boye 2012: 245). Flere andre studier har fundet samme korrelation mellem rækkefølge og skopusforhold, fx Bybee 1985, Cinque 1999, Foley \& Van Valin 1984, Hengeveld 1989 og Hengeveld \& Mackenzie 2008.

Tværsproglige skopustendenser kan beskrives ud fra konceptuel dependens, som jeg i forste omgang vil gennemgå ud fra Dansk Funktionel Lingvistiks model for lagdelt indholdsstruktur. Modellen er præsenteret i (3).

(3) illokution

proposition

sagforhold

prædikat

entitet

(Baseret på Boye 2012: 249 \& Harder 2005: 104-105)

Hvert lag i modellen har skopus over lagene nedenunder sådan at fx illokutioner har skopus over propositioner (Harder 2005: 107). Den lagdelte indholdsstruktur afspejler konceptuel dependens ved at hvert lag i lagdelingen 
er konceptuelt afhængigt af laget under (Harder 1996: 276). For eksempel er illokutioner som assertioner afhængige af propositioner fordi man ikke kan assertere noget uden en proposition. For at kunne assertere noget er det nødvendigt at have en proposition som kan asserteres. Den konceptuelle dependens mellem lagene i den lagdelte indholdsstruktur afspejles i skopustendenser mellem affikser. Som nævnt ovenfor har epistemiske affikser skopus over tempusaffikser. Det kan forklares ud fra at tempus-affikser som regel opererer på sagforhold (Harder 2005: 106) mens epistemiske affikser som regel opererer på propositioner (Boye 2012: 195). Det at propositioner er konceptuelt afhængige af sagforhold afspejles altså i de individuelle affiksers skopusegenskaber, hvilket igen afspejles i rækkefølgetendenser sådan at tempusaffikser som regel står tættere på roden end affikser som udtrykker epistemisk modalitet.

Tværsproglige rækkefølgetendenser afspejler altså skopustendenser, som afspejler konceptuel dependens, og den lagdelte indholdsstruktur kan bruges til at beskrive hvordan forskellige lingvistiske elementer er konceptuelt afhængige af hinanden.

\section{Hypotese}

Ud fra idéen om at rækkefølgetendenser afspejler konceptuel dependens er det muligt at opstille en hypotese om rækkefølgen af valensændrende affikser baseret på den lagdelte indholdsstruktur fordi den kan bruges til at beskrive hvilke konceptuelle dependenser der er mellem forskellige betydningsniveauer. Hvis man kan identificere de valensændrende affiksers placering i den lagdelte indholdsstruktur, kan man altså opstille en hypotese om affiksernes rækkefølge. Modellen for lagdelt indholdsstruktur kan dog ikke umiddelbart bruges som et værktøj til at udlede den konceptuelle dependens mellem valensændrende affikser. Valensændrende affikser påvirker verbets argumentstruktur og semantiske roller og må altså alle operere på prædikatet. Når de alle opererer på prædikatet er det umuligt at udlede hvordan de forskellige valensændrende affikser er konceptuelt afhængige af hinanden.

Valensændrende affikser kan deles op i to grupper - dem som påvirker inventaret af semantiske roller, og dem som ikke gør (Kulikov 2011). Både applikativer og kausativer påvirker inventaret af semantiske roller. Applikativer tilføjer en ny ikke-agent (fx patient, instrument), og kausativer tilføjer en ny agent/'causer' som ikke er der i den uafledte konstruktion (Kulikov 2011: 386, 389). Antipassiver påvirker til gengæld ikke inventa- 
ret af semantiske roller men forhindrer en participant i at blive udtrykt som direkte argument (Kulikov 2011: 374, 380, Foley 2007: 430) mens participanten stadig er impliceret (Keenan \& Dryer 2007: 352). Fra nu af refererer jeg til de to grupper som henholdsvis rollebevarende og rolleandrende affikser. Beskrevet i mere semantiske termer er de rollebevarende affiksers funktion at ændre hvordan de semantiske roller bliver fordelt i forhold til informationsstruktur, fx hvilke semantiske roller som står i diskursivt fokus. For eksempel er antipassivers funktion ud over at fjerne patienten som direkte argument enten at fremhæve agenten eller at gøre patienten mindre prominent (Foley 2007: 430-423).

Logisk set må rollebevarende affikser være konceptuelt afhængige af rolleændrende affikser. De rollebevarende affikser ændrer prædikatets inventar af semantiske roller, og det inventar må allerede være fastlagt før de semantiske roller kan fordeles på grammatiske relationer som rollebevarende affikser gør. Hvis rollebevarende affikser er konceptuelt afhængige af rolleændrende affikser, må man forvente at der er en tendens til at rollebevarende affikser har skopus over rolleændrende affikser, og at rollebevarende affikser vil stå længere fra roden end rolleændrende affikser. Undersøgelsens hypotese er altså at applikativer og kausativer står længere fra verbalroden end antipassiver.

\section{Data og databehandling}

Hypotesen præsenteret i afsnit 4 bliver undersøgt i et sample på 50 polysyntetiske sprog baseret på Fortescues (2016) liste over polysyntetiske sprog. Undersøgelsen bruger data fra polysyntetiske sprog fordi de tillader lange strenge af verbalaffikser og altså rent praktisk giver mere information om affiksrækkefølge end sprog med kun få verbalaffikser. Samplet er et genetisk og geografisk stratificeret sandsynligheds-sample (probability sample) med enkelte træk fra convenience samples (jf. Bakker 2011) fordi udvælgelsen af sprogene til dels er baseret på hvilke sprog der findes detaljerede beskrivelser for. Samplet blev udformet ud fra Glottologs (Hammarström, Forkel \& Haspelmath 2016) genetiske klassifikation af sprog, og en liste over sprogene som indgår i samplet med information om geografi og familieforhold står til sidst i artiklen. Ud af de 50 sprog i samplet var der tilgængeligt materiale for $43 \operatorname{sprog}^{1}$.

1. Denne samplings-praksis er i overensstemmelse med andre typologiske undersøgelser, fx Boye et al. (2015) 
De valensændrende affikser i hvert sprog blev identificeret ved at gennemlæse referencegrammatikker, og ud fra både beskrivelser og eksempelsætninger blev affikser kategoriseret ud fra definitionerne givet i afsnit 2 . Rækkefølgen af affikser i hvert sprog blev også identificeret enten ud fra beskrivelser i grammatikken, ofte i form af oversigtstabeller over rækkefølgen af affikser, eller gennem eksempelsætninger. Denne artikel beskæftiger sig kun med affikser som entydigt står i en bestemt rækkefølge i et givent sprog. Affikser som står i fleksibel rækkefølge, eller hvor man ikke kan deducere sig frem til rækkefølgen ud fra de tilgængelige grammatikker, er ikke inkluderet i artiklen.

\section{Resultater}

I det følgende skal < læses som 'står tættere på roden end'. Det vil sige at antipassiv < applikativ læses som 'antipassiv står tættere på roden end applikativ' uafhængigt om der er tale om præfikser eller suffikser.

I den overordnede rækkefølge af antipassiver, applikativer og kausativer kan man tale om tre forskellige rækkefølger: a) applikativer og kausativer, b) applikativer og antipassiver og c) antipassiver og kausativer. Tabel 1 nedenfor viser oversigten over hvor mange sprog som udviser de forskellige rækkefølger.

\begin{tabular}{|ll|}
\hline Rækkefølge & Antal sprog \\
\hline applikativ $<$ kausativ & 1 \\
kausativ $<$ applikativ & 5 \\
\hline antipassiv $<$ applikativ & 3 \\
applikativ $<$ antipassiv & 1 \\
\hline antipassiv $<$ kausativ & 2 \\
kausativ $<$ antipassiv & 1 \\
\hline
\end{tabular}

Tabel 1: Oversigt over affiksrekkefolge

Som det fremgår af tabellen er der ret få sprog som udviser de forskellige rækkefølger med højst fem ud af 43 sprog (kausativ < applikativ). Det 
skyldes at der er en række forudsætninger for at et sprog udviser en given rækkefølge: 1) Sproget skal have begge affikser, fx både en applikativ og en antipassiv, 2) de to affikser skal stå på samme side af roden (man kan ikke bestemme hvilket affiks står tættere på roden når det drejer sig om et suffiks og et præfiks), 3) de to affikser skal stå i en fast rækkefølge, og 4) rækkefølgen skal fremgå af materialet analysen er baseret på. Konsekvensen af at arbejde med så lille en mængde data bliver diskuteret $\mathrm{i}$ afsnit 7. I de følgende afsnit vil data for hver rækkefølge blive gennemgået med udvalgte eksempler.

\subsection{Applikativ \& kausativ}

Ud af seks sprog som har både applikativer og kausativer udviser fem sprog rækkefølgen kausativ < applikativ. Det drejer sig om sprogene kutenai, chukchi, tapieté, tetelcingo nahuatl og ashéninka perené. Kutenai har to kausativer og tre applikativer som alle står i rækkefølgen kausativ < applikativ som det ses i tabel 2.

\begin{tabular}{|l|l|l|l|l|}
\hline $\mathbf{0}$ & $\mathbf{+ 1}$ & $\mathbf{+ 2}$ & $\mathbf{+ 3}$ & $\mathbf{+ 4}$ \\
\hline ROD & -6 "CAUS" & $-(i) t$ "CAUS/APPL" & $-k i \sigma_{6}-i k_{6}$ "APPL" & $-m u$ "APPL" \\
& & & & \\
\hline
\end{tabular}

Tabel 2: Affiksrakkefolge i kutenai (baseret på Morgan 1991)

Som det ses i tabellen, kan suffikset -(i)t både udtrykke kausativ og applikativ, men i begge tilfælde står affikserne i rækkefølgen kausativ < applikativ. Derudover har kutenai to applikativer på plads +3 og +4 som står længere fra roden end kausativen på plads +1. (4) nedenfor viser et eksempel på -(i) $t$ som kausativ.

(4a) Pup 'to die'

(4b) Pup-it' 'to kill'

(Morgan 1991: 300)

Ashéninka perené har én kausativ og én applikativ som står i rækkefølgen kausativ < applikativ som det fremgår af tabel 3.

\begin{tabular}{|l|l|l|}
\hline $\mathbf{0}$ & $\mathbf{+ 1}$ & $\mathbf{+ 2}$ \\
\hline ROD & $-a k^{\text {'CAUS' }}$ & $-a N t^{\text {'APPL' }}$ \\
\hline
\end{tabular}

Tabel 3: Affiksrakkefolge i ashéninka perené (baseret på Mihas 2010) 
Ashéninka perené har også et kausativt præfiks ( $m i-)$, men da det ikke står på samme side af roden som applikativen, er det ikke relevant for denne undersøgelse. Eksempel (5) nedenfor viser et eksempel på kausativen -ak.

$$
\begin{aligned}
& Y=a N t-a-v a i-t-a k-a k-i=r i . \\
& \text { 3M.A=work-EP-DUR-EP-CAUS-PRF-REAL=3M.OBJ } \\
& \text { 'He made them work [enabling the workers to get food].' } \\
& \text { (Mihas 2010: 129) }
\end{aligned}
$$

Til sidst har både chukchi, tapieté og tetelcingo nahuatl hver én kausativ og én applikativ som står i rækkefølgen kausativ < applikativ.

Kun ét sprog, tlahuitoltepec mixe, udviser den modsatte rækkefølge, applikativ < kausativ. Tabel 4 nedenfor giver en oversigt over de relevante affikser i tlahuitoltepec mixe.

\begin{tabular}{|l|l|l|l|l|}
\hline $\mathbf{- 4}$ & $\mathbf{- 3}$ & $\mathbf{- 2}$ & $\mathbf{- 1}$ & $\mathbf{0}$ \\
\hline$t u k$ - 'CAUS' & $a k$ - 'PASS/CAUS' & $t a$ - 'APPL' & $p a t$ - 'APPL' & ROD \\
\hline & $a$ - 'CAUS' & & $j e ̈ n-~ ' A P P L '$ & \\
\hline & & & $p u^{\prime}$ ' APPL' & \\
\hline & & & $p a$ - 'APPL' & \\
\hline & & & $n \ddot{e}$ - 'APPL' & \\
\hline
\end{tabular}

Tabel 4: Affiksrakkefolge i tlahuitoltepec mixe (baseret på Romero-Méndez 2008)

Som tabel 4 viser, står der tre kausativer på plads -4 og -3 mens der står seks applikativer på plads -2 og -1. Alle kausativerne og applikativerne i tlahuitoltepec mixe står altså i rækkefølgen applikativ < kausativ. (6) og (7) giver eksempler på kausativen $a^{-}$og applikativen $p a-$.

$$
\begin{array}{lll}
\text { (6) } & \text { Carlos } y \text {-a-jokx- } \ddot{e}-p & y \ddot{e} ' \\
& \text { Carlos 3A-CAUS-be.warm-INCH-ASPECT/MOOD } & \text { DEM.MED } \\
& \text { 'Carlos heats the water up.' (Romero-Méndez 2008: 369) } \\
\text { (7a) } & \text { put 'to run' } \\
\text { (7b) paput 'to run after someone', 'to chase' } & \\
& \text { (Romero-Méndez 2008: 392) }
\end{array}
$$$$
y \ddot{e}
$$$$
n \ddot{j} \text {. }
$$

(7a) put'to run'

Rækkefølgen af applikativer og kausativer er opsummeret i tabel 5. 


\begin{tabular}{|lll|}
\hline Sprog & Kausativ $<$ applikativ & Applikativ $<$ kausativ \\
tlahuitoltepec mixe & & $\mathrm{X}$ \\
ashéninka perené & $\mathrm{X}$ & \\
kutenai & $\mathrm{X}$ & \\
chukchi & $\mathrm{X}$ & \\
tapieté & $\mathrm{X}$ & \\
\hline
\end{tabular}

Tabel 5: Rakkefolgen af applikativer og kausativer

\subsection{Antipassiv \& applikativ}

Ud af fire sprog med antipassiver og applikativer har tre sprog rækkefølgen antipassiv < applikativ. Det drejer sig om ainu, mosetén-chimané og ashéninka perené. Ainu har én antipassiv som står tættere på roden end sprogets tre applikativer som vist i tabel 6 nedenfor.

\begin{tabular}{|l|l|l|l|l|}
\hline$-\mathbf{4}$ & $\mathbf{- 3}$ & $\mathbf{- 2}$ & $\mathbf{- 1}$ & $\mathbf{0}$ \\
\hline$e$ - "APPL" & $i$ - "ANTIP" & $k o$ - "APPL" & $i$ - "ANTIP" & ROD \\
\hline$o$ - "APPL" & & & & \\
\hline
\end{tabular}

Tabel 6: Affiksrakkefolge i ainu (baseret på Refsing 1986)

De tre applikativer på plads -4 og -2 står altså længere fra roden end antipassiven på plads -1 . Bemærk at antipassiven $i$ - også kan stå på plads -3 , hvilket betyder at ainu også udviser den modsatte rækkefølge, applikativ < antipassiv. (8), (9) og (10) nedenfor er eksempler på antipassiven og to af de tre applikativer.

$$
\begin{array}{lll}
e & \text { cisehe } \underline{\underline{u n}} & \text { hosipi! } \\
\text { 2SG home } \underline{\underline{\mathrm{PP}}} & \text { return } \\
\text { 'Return to your home!' } &
\end{array}
$$

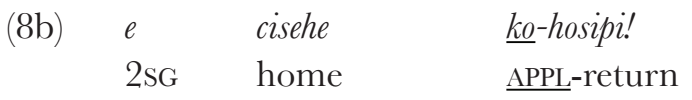

'Return to your home!' (Refsing 1986: 182)

(9) ...nep e kar yakka e what 2SG do even.though 2SG APPL-make.good ASSERT '... no matter what you do, you gain (= make good) by it.' (Refsing 1986: 182) 
I (9) er der et implicit argument, hvilket kan ses i oversættelsen “ . . by it", men ifølge Refsing kan argumentet også være eksplicit selvom det er mere sjældent (Refsing 1986: 182).

$$
\begin{aligned}
& \text { wen kamuy a kor nispa nukar yak anak nekon } \underline{i}-k i \\
& \text { be.bad god 1SG ATTR. hus- see if TOP how ANTIP- } \\
& \text { PP band do } \\
& \text { ya, an sitoma ruwene. } \\
& \text { Q INDEF fear ASSERT }
\end{aligned}
$$

'If the evil god sees you, my husband, one must be fearful of how he will act (do something).' (Refsing 1986: 181)

Antipassiven $i$-i (10) detransitiverer det ellers transitive verbum $k i$ ('do') ved at fjerne patienten som direkte argument. Patienten er dog stadig impliceret i oversættelsen "... (do something)" (Refsing 1986: 181).

Mosetén-chimané har to applikativer og en antipassiv, hvoraf én af applikativerne står længere fra roden end antipassiven. Den anden applikativ står på samme plads som antipassiven og står altså hverken tættere eller længere fra roden. En oversigt over affiksrækkefølgen i mosetén-chimané er præsenteret nedenfor i tabel 7.

\begin{tabular}{|l|l|l|}
\hline $\mathbf{0}$ & $\mathbf{+ 1}$ & $\mathbf{+ 2}$ \\
\hline ROD & - tyi 'APPL' & $-b i$ 'APPL' \\
\hline & $-k i$ 'PASS/ANTIP' & \\
\hline
\end{tabular}

Tabel 7: Affiksrekkefolge i mosetén-chimané (baseret på Sakel 2014)

Som det kan ses ovenfor står antipassiven (som også kan fungere som passiv) - $k i$ tættere på roden end applikativen -bi. Eksempler på antipassiven og applikativen er præsenteret i (11) og (12).

$$
\begin{array}{lll}
M \ddot{o}{ }^{\prime} & \text { roro' } & \text { raem'- } y a-k \underline{k}^{\prime}{ }^{\prime} . \\
\text { 3F.SG } & \text { vermin } & \text { bite-SM-ANTIP-F.S }
\end{array}
$$

'The vermin has bitten (someone/something).' (Sakel 2014: 308)

$$
\begin{array}{llllll}
\text { Mö' } & \text { Autralia } & a y-i-j o-i-{ }^{\prime} & a k a^{\prime}-y a^{\prime} & \text { si-ti-' } & k o ̈ s i n a ̈-k h a n \\
\text { 3F.SG } & \text { Aurelia } & \text { come-F.S-SM- } & \text { house-AD } & \text { enter-SM-F.S } & \text { kitchen-IN } \\
& & \text { INCEP-F.S }
\end{array}
$$




$$
\begin{array}{lll}
j e b-a-k s e-b \underline{i}^{-} & \text {saeks-e-dye } & \ddot{a} w \ddot{a} \text {-si'- } \ddot{\prime} . \\
\text { eat-SM-3PL.O-APPL-F.S } & \text { eat-SM-NMLZ } & \text { child-LINKER.F-PL }
\end{array}
$$

'Aurelia came to the house, entered the kitchen and ate the food of the children (against their will).' (Sakel 2014: 308).

Ifølge Sakel er suffikset -bi i (12) en applikativ som tilføjer et direkte argument der udtrykker en participant hvis vilje handlingen er imod. Her er argumentet $\ddot{a} w \ddot{a}$-si'-̈̈n ('børnene') som står som direkte argument.

Det sidste eksempel på rækkefølgen antipassiv < applikativ kommer fra ashéninka perené med antipassiven $-a \mathcal{N} t$ og applikativen $-a \mathcal{N} t$ som vises i tabel 8 .

\begin{tabular}{|l|l|l|l|}
\hline $\mathbf{0}$ & $\mathbf{+ 1}$ & $\mathbf{+ 2}$ & $\mathbf{+ 3}$ \\
\hline ROD & $\begin{array}{l}-a N t \\
\text { "ANTIP" }\end{array}$ & $\begin{array}{l}-a k \\
\text { "CAUS" }\end{array}$ & $\begin{array}{l}-a N t \\
\text { "APPL" }\end{array}$ \\
\hline
\end{tabular}

Tabel 8: Affiksrakkefølge i ashéninka perené (baseret på Mihas 2010)

Det er ikke klart i hvor høj grad de to morfemer er relateret, men de har to forskellige funktioner og står på to forskellige pladser. (13) og (14) er eksempler på affikserne.

$$
\begin{aligned}
& \text { Mantsiya-ri }=r a \quad i=\mathcal{N} \text {-pok-e pashini, pashini } \\
& \text { be.sick-ADJ=DEM 3M.S =IRR-come-IRR another another } \\
& n o=s a a-t-a \mathrm{~N} t-a=r i=r i \text {. } \\
& 1 \mathrm{SG} \cdot \mathrm{A}=\text { bathe-EP-APPL}-\mathrm{REAL}=3 \mathrm{M} \cdot \mathrm{O}=\mathrm{RLVZ}
\end{aligned}
$$

'When another sick person comes, I steam-bathe him with a different herb.' (Mihas 2010: 130)

I (13) er det helsætningen pashini nosaatantariri ('I steam-bathe him with a different herb') som er relevant. Verbet saa ('bathe') er transitivt når det er uafledt. I dette eksempel, hvor det er afledt, tager det tre direkte argumenter. Agenten og patienten er markeret på verbet (henholdsvis $n o=\mathrm{og}$ =ri), og derudover står instrumentet pashini ('another'/'a different herb') som direkte argument.

$$
\begin{array}{lll}
n=\text { otsitzi-te } & t e & y=\text { atsik- } \underline{a N t}-a \\
\text { 1sG.POSS=dog-POSS } & \text { NEG.REAL } & \text { 3M.s }=\text { bite- } \underline{\text { ANTIP-IRR }}
\end{array}
$$

'My dog doesn't bite.' (Mihas 2010: 130) 
I (14) fjerner antipassiven - $a$ Nt patienten som direkte argument fra et ellers transitivt verbum atsik ('bite') mens patienten stadig er impliceret (hunden bider ikke ud i det blå, men nogen eller noget).

Som nævnt ovenfor kommer det eneste eksempel på den modsatte rækkefølge applikativ < antipassiv fra ainu, som har begge rækkefølger som vist i tabel 6 ovenfor. Fordelingen af rækkefølgen antipassiv < applikativ er opsummeret i tabel 9.

\begin{tabular}{|lll|}
\hline Sprog & antipassiv $<$ applikativ & applikativ $<$ antipassiv \\
Ainu & $\mathrm{X}$ & $\mathrm{X}$ \\
Mosetén-chimané & $\mathrm{X}$ & \\
Ashéninka perené & $\mathrm{X}$ & \\
\hline
\end{tabular}

Tabel 9: Rakkefølgen af antipassiver \& applikativer

\subsection{Kausativ \& antipassiv}

Kun to sprog i samplet indeholder data om rækkefølgen af kausativer og antipassiver. Ashéninka perené har en antipassiv som står tættere på roden end kausativen som det ses i tabel 8 ovenfor. (5) og (14) ovenfor giver eksempler på kausativen og antipassiven. Aleut har begge rækkefølger af kausativ og antipassiv med en kausativ som kan stå både før og efter antipassiven som vist i tabel 10 .

\begin{tabular}{|l|l|l|l|}
\hline $\mathbf{0}$ & $\mathbf{+ 1}$ & $\mathbf{+ 2}$ & $\mathbf{+ 3}$ \\
\hline ROD & - ch $\hat{x} i$ “CAUS" & $-q a \hat{g} i$ “ANTIP" & - ch $\hat{x} i$ “CAUS" \\
\hline
\end{tabular}

Tabel 10: Affiksrakkefolge i aleut (baseret på Bergsland 1997)

Fordelingen af rækkefølgen af kausativer og antipassiver er vist i tabel 11.

\begin{tabular}{|lll|}
\hline Sprog & antipassiv $<$ kausativ & kausativ $<$ antipassiv \\
Aleut & $\mathrm{X}$ & $\mathrm{X}$ \\
Ashéninka perené & $\mathrm{X}$ & \\
\hline
\end{tabular}

Tabel 11: Rekkefolgen af antipassiver \& kausativer

\section{Evaluering af hypotese og konklusion}

Som beskrevet i afsnit 4 forudsiger undersøgelsens hypotese at antipassiver står tættere på roden end applikativer og kausativer. Undersøgelsens data 
synes at stemme overens med hypotesen. Der er en meget lille overvægt af sprog der henholdsvis har rækkefølgen antipassiv < applikativ og antipassiv < kausativ. Det at fem ud af seks sprog har rækkefølgen kausativ < applikativ stemmer også overens med hypotesen fordi den ikke siger noget om rækkefølgen af applikativer og kausativer, kun at de står længere fra roden end antipassiver. I teorien betyder en bekræftelse af hypotesen at rækkefølgen af valensændrende affikser i lighed med andre typer affikser afspejler skopusforhold mellem affikserne, og at skopusforholdene kan beskrives ud fra konceptuel dependens.

Resultaterne præsenteret her skal dog tages med store forbehold på grund af den lille mængde data. Ud af et sample på 50 sprog kommer dataene for de tre rækkefølger som er gennemgået her, kun fra otte forskellige sprog, så man kan altså ikke tale om tværsproglige tendenser. Dog giver dette studie indblik i hvordan fremtidige studier bør udføres. Det viser sig at et sample på 50 sprog er for lille til at undersøge rækkefølgen af antipassiver, applikativer og kausativer. Det vil sige at fremtidige studier må udvide datagrundlaget enten ved at arbejde med et større sample eller ved for eksempel at inddrage eksperter i specifikke sprog som kan give mere information end hvad der fremgår af grammatikker. En anden mulighed er ikke at arbejde med et tilfældigt sample men at udvælge sprog som man i forvejen ved har antipassiver, applikativer og kausativer.

Denne artikel giver altså ikke klare resultater, men præsenterer dog en teoretisk funderet hypotese for tendenser i rækkefølgen af valensændrende affikser som kan bruges i fremtidige undersøgelser, og kommer frem til at videre studier må have et større datagrundlag for at lave dybdegående undersøgelser af rækkefølgen af antipassiver, applikativer og kausativer.

\section{Forkortelser}

$1-1$. person

$2-2$. person

$3-3$. person

A - agent-agtigt argument ved kanonisk transitivt verbum

$\mathrm{AD}$ - adessiv

ADJ - adjektiv

APPL - applikativ

ASSERT - assertiv

ATTR - attributiv

BEN - benefaktiv 
CAUS - kausativ

DEM - demonstrativ

DUR - durativ

EP - epentetisk

$\mathrm{F}-$ femininum

INCEP - inceptiv

INCH - inchoativ

INDF - indefinit

IN - inessiv

IRR - irrealis

$\mathrm{M}-$ maskulinum

MED - medial

NEG - negation, negativ

OBJ - objekt

PASS - passiv

POss - possessive

$\mathrm{PP}-$ postposition

PRF - perfektum

Q - spørgsmålspartikel/-markør

REAL - realis

RLVZ - relativizer

$\mathrm{S}$ - ene argument ved kanonisk intransitivt verbum

$\mathrm{SG}$ - singularis

$\mathrm{SM}-$ stammemarkør

TOP - topic

Sample

\begin{tabular}{|l|l|l|}
\hline \multicolumn{1}{|c|}{ Område } & \multicolumn{1}{c|}{ Sprogfamilie } & \multicolumn{1}{c|}{ Sprog } \\
\hline Nordamerika & Eskimo-Aleut & Aleut \\
\hline Nordamerika & Algic & Arapaho \\
\hline Nordamerika & Siouan & Dakota \\
\hline Nordamerika & Isolat & Kutenai \\
\hline Nordamerika & Tsimshian & Coast Tsimshian \\
\hline Nordamerika & Haida & Haida \\
\hline Nordamerika & Chimakuan & $\begin{array}{l}\text { Indgår ikke (intet } \\
\text { materiale) }\end{array}$ \\
\hline Nordamerika & Uto-Aztecan & Shoshone \\
\hline Nordamerika & Sahaptian & Yakima \\
\hline Nordamerika & Chinookan & Chinook \\
\hline Nordamerika & Isolat & Klamath \\
\hline Nordamerika & Palaihnihan & $\begin{array}{l}\text { Indgår ikke (intet } \\
\text { materiale) }\end{array}$ \\
\hline
\end{tabular}




\begin{tabular}{|c|c|c|}
\hline Nordamerika & Shastan & Shasta \\
\hline Nordamerika & Isolat & Washo \\
\hline Nordamerika & Kiowa-Tanoan & Kiowa \\
\hline Nordamerika & Caddoan & Wichita \\
\hline Nordamerika & Muskogean & Creek \\
\hline Nordamerika & Isolat & Yuchi \\
\hline Mellemamerika & Tarascan & Purepecha \\
\hline Mellemamerika & Totonacan & $\begin{array}{l}\text { Yecuatla } \\
\text { Totonac }\end{array}$ \\
\hline Mellemamerika & Mixe-Zoque & Ayutla Mixe \\
\hline Mellemamerika & Uto-Aztecan & $\begin{array}{l}\text { Tetelcingo } \\
\text { Nahuatl }\end{array}$ \\
\hline Mellemamerika & Uto-Aztecan & Pipil \\
\hline Mellemamerika & Mayan & Itzá \\
\hline Sydamerika & Araucanian & Mapudungun \\
\hline Sydamerika & Arawakan & $\begin{array}{l}\text { Ashéninka } \\
\text { Perené }\end{array}$ \\
\hline Sydamerika & Arawakan & Lokono \\
\hline Sydamerika & Aymara & $\begin{array}{l}\text { Southern } \\
\text { Aymara }\end{array}$ \\
\hline Sydamerika & Nambiquaran & $\begin{array}{l}\text { Southern } \\
\text { Nambikuára }\end{array}$ \\
\hline Sydamerika & Nambiquaran & Mamaindé \\
\hline Sydamerika & Isolat & Mostén-Chimané \\
\hline Sydamerika & Harakmbut & $\begin{array}{l}\text { Indgår ikke (intet } \\
\text { materiale) }\end{array}$ \\
\hline Sydamerika & Cahuapenan & Jebero \\
\hline Sydamerika & Yanomam & Sanumá \\
\hline Sydamerika & $\begin{array}{l}\text { Guahibo (skal } \\
\text { repræsenteres af } \\
\text { to sprog i } \\
\text { samplet) }\end{array}$ & $\begin{array}{l}\text { Indgår ikke (intet } \\
\text { materiale) }\end{array}$ \\
\hline Sydamerika & Tupian & $\begin{array}{l}\text { Cocama- } \\
\text { Cocamilla }\end{array}$ \\
\hline Sydamerika & Tupian & Tapiété \\
\hline Sydamerika & Nadahup & $\begin{array}{l}\text { Indgår ikke (intet } \\
\text { materiale) }\end{array}$ \\
\hline Sydamerika & Pano-Tacanan & Matsés \\
\hline Sydamerika & Pano-Tacanan & $\begin{array}{l}\text { Cashibo- } \\
\text { Cacataibo }\end{array}$ \\
\hline Sydamerika & Caraban & Galibi Carib \\
\hline Sydamerika & Caraban & $\begin{array}{l}\text { E'napa } \\
\text { Woromaipu }\end{array}$ \\
\hline Sydamerika & Makú (isolat) & $\begin{array}{l}\text { Indgår ikke (intet } \\
\text { materiale) }\end{array}$ \\
\hline Eurasien & $\begin{array}{l}\text { Chukotko- } \\
\text { Kamchatkan }\end{array}$ & Chukchi \\
\hline Eurasien & Isolat & Ainu \\
\hline Eurasien & Austroasiatic & Perenga \\
\hline Eurasien & Sino-Tibetan & Dumi \\
\hline Oceanien/Australien & Sepik & Alamblak \\
\hline Oceanien/Australien & Southern Daly & Murrinh-Patha \\
\hline
\end{tabular}




\section{Om forfatteren}

Jessie Leigh Nielsen, cand.mag. i lingvistik, Københavns Universitet.

\section{Litteratur}

Bakker, D. (2011): Language sampling. I: The Oxford handbook of linguistic typology. Song, J.J. (red.). Oxford: Oxford University Press, 100-127.

Bergsland, K. (1997): Aleut grammar: Unangam tunuganaan achixaasix. University of Alaska Fairbanks: Alaska Native Language Center.

Boye, K. (2012): Epistemic meaning: A crosslinguistic and functional-cognitive study. Berlin/Boston: de Gruyter Mouton.

Boye, K, van Lier, E. \& Brink, E. T. (2015): Epistemic complementizers: A cross-linguistic survey. Language Sciences, 1-17.

Bybee, J. (1985): Morphology: A study of the relation between meaning and form. Amsterdam, Philadelphia: Benjamins.

Cinque, G. (1999): Adverbs and functional heads: A crosslinguistic perspective. Oxford: Oxford University Press.

Foley, W.A. (2007): A typology of information packaging in the clause. I: Language typology and syntactic description, vol. 1 (2. udg.). Shopen, T. (red.). Cambridge: Cambridge University Press, 362-446.

Foley, W.A. \& van Valin Jr. R.D. (1984): Functional syntax and Universal Grammar. Cambridge: Cambridge University Press.

Fortescue, M. (2016): Polysynthesis: A diachronic and typological perspective. I: Oxford research encyclopedia of linguistics. Aronoff, M. (red.). Oxford: Oxford University Press. http://linguistics.oxfordre.com (lokaliseret 13.5.18).

Hammarström, H., Forkel, R. \& Haspelmath, M. (2017): Glottolog 3.1. http://glottolog.org (lokaliseret 1.1.18).

Harder, P. (1996): Functional semantics: A theory of meaning, structure, and tense in English. Berlin, New York: Mouton de Gruyter.

Harder, P. (2005): Lagdelt sætningsstruktur. I: Dansk funktionel lingvistik: en helhedsforståelse af forholdet mellem sprogstruktur, sprogbrug og kognition. EngbergPedersen, E., Fortscue, M., Harder, P., Heltoft, L., Herslund, M. \& Falster Jacobsen, L. (red.). København: Københavns Universitet, Handelshøjskolen i København \& Roskilde: Roskilde Universitetscenter, 101-111.

Haspelmath, M. (2010): Comparative concepts and descriptive categories in crosslinguistic studies. Language 86 (3), 663-687.

Haspelmath, M. (2011): On S, A, P, T, and R as comparative concepts for alignment typology. Linguistic Typology 15, 535-567. 
Hengeveld, K. (1989): Layers and operators in functional grammar. Fournal of Linguistics 25 (1), 127-157.

Hengeveld, K. \& Mackenzie, J.L. (2008): Functional Discourse Grammar: A typologically-based theory of language structure. Oxford: Oxford University Press.

Keenan, E.L. \& Dryer, M.S. (2007): Passives in the world's languages. I: Language typology and syntactic description, vol. 1 (2. udg.). Shopen. T. (red.). Cambridge: Cambridge University Press, 325-361.

Kittilä, S. (2011): Transitivity typology. I: The Oxford handbook of linguistic typology. Song, J.J. (red.). Oxford: Oxford University Press, 346-367.

Kulikov, L. (2011): Voice typology. I: The Oxford handbook of linguistic typology. Song, J.J. (red.). Oxford: Oxford University Press, 368-398.

Mihas, E. (2010): Essentials of Ashéninka Perené grammar. Ph.d.-afhandling, University of Wisconsin-Milwaukee.

Morgan, L. R. (1991): A description of the Kutenai language. Ph.d.-fhandling, University of California at Berkeley.

Refsing, K. (1986): The Ainu language: The morphology and syntax of the Shizuanai dialect. Århus: Aarhus University Press.

Romero-Méndez, R. (2008): A reference grammar of Ayutla Mixe (Tukyo'm Ayuujk). Ph.d.-afhandling. University at Buffalo.

Sakel, J. (2004): A grammar of Mosetén. Berlin, New York: Mouton de Gruyter. 